\title{
ANALYSIS OF THE AIRCRAFT ACCIDENTS OCCURRED IN UNITS OF THE POLISH AIR FORCE ACADEMY IN THE YEARS 1970-1994
}

DATA PRZESŁANIA: 12.12 .2015 |DATA AKCEPTACJI: 12.12 .2015 | JEL CODE: 123

\begin{abstract}
Assoc. Prof. PhD Jarosław Kozuba
Vice-Rector for Science, Polish Air Force Academy, Dęblin, the Republic of Poland e-mail: prorek_ds.nauk@wsosp.pl
\end{abstract}

\section{MSc Marek Kustra}

Student of the Polish Air Force Academy, Faculty of National Security and Logistics, Department of National Security, Dęblin, the Republic of Poland e-mail: mark140292@gmail.com

\section{PhD Justyna Tomaszewska}

Faculty of National Security and Logistics, Polish Air Force Academy, Dęblin, the Republic of Poland e-mail: j.tomaszewska@wsosp.pl

ABSTRACT

KEYWORDS
The article was written on basis of Flight safety brochures published by the Polish Air Force Academy from 1975 to 1998 . The first part is dedicated for actual training process of the Polish military pilots. The second component focuses on the main causes of the occurrence of aircraft accidents in units of the Polish Air Force Academy in concerned period of time. The further part of the article is dedicated to analysis of aircraft accidents occurred in military aviation training units in years 1970-1994.

flight safety, human factor, training, aviation accident

\section{INTRODUCTION}

A pilot's profession is as beautiful as it is demanding. There is a conviction that a pilot should have some attributes to fulfill his duties properly in safety manner, for example: theoretical knowledge, practical skills, a lot of luck and aviation flair and of course very good health condition. But it is not everything. Other necessary features are: ability to anticipate, situational awareness, also spatial imagination. These people should be reasonable, as well as mentally stable (Majewski, 1984b). 
The human factor has always played an important role and had influence on safety of flights regardless the type of aviation and performed tasks. "The concept of human factors in aviation must be understood as an action (or inaction) of the pilot, mechanics, air traffic controller, etc. or any other person in the relationship between human and the interdependent aviation environment" (Makarowski, Smolicz, 2012, p. 358). Due to responsibility of many people for the safety tasks performance, we have to know aviation activity is quite specific. Especially important is the fact that one human is responsible for life of others. It mainly concerns the pilot profession but also an air traffic controller and many other professions. On basis of that, it seems that comprehensive training, improvement of the aviation personnel's knowledge and skills can cause the decrease of the number of aviation accidents. It is important to know that members of aviation personnel are people "[...] who have a valid license or a certificate of competency and is entered into the national register of aviation personnel or other appropriate register kept in accordance with separate regulations" (The Polish Aviation Law of 3 July 2002, art. 94).

The article was written to present that, not only currently, the human factor seems to be the weakest element in aviation safety system in air forces (nowadays tactical and technical parameters of military aircraft exceed human abilities). For this purpose, there was prepared the percentage ratio of accidents caused by the human factor to the overall number of these accidents in units of the Polish Air Force Academy in considered period of time. It is easy to understand that the aviation safety system consists of the following factors: human, technical (especially aircraft), environmental (natural and artificial one) and organizational.

\section{THE ACTUAL TRAINING OF MILITARY PILOTS IN POLAND}

A pilot's training is a long-lasting and multi-step process, which is showed on figure 1 . The initial three levels take place at the Polish Air Force Academy. A silhouette of the military pilot is formed in the aviation school so it is a very important part of the training process. The theoretical knowledge, practical skills and habits gained at the university will be used in military units.

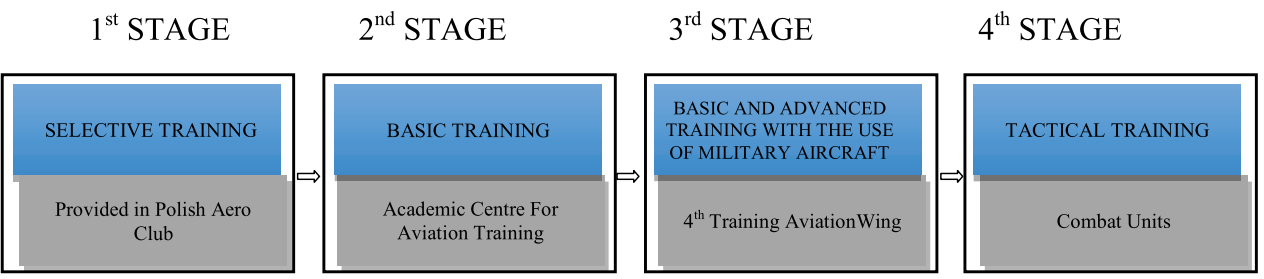

Figure 1. The actual training of military pilots in Poland being in force from 01.10.2012 Source: own material based on: Bogusz, Kulik, 2014, p. 138.

The use of correct methodology, adequate technical aids, also motivation of the trained person allows to gain appropriate efficiency and to maintain proper training quality. "In general, it can be concluded that selecting of teaching methods is important in system of: objectives - contents rules - methods - organizational forms - methods of teaching - learning and depends on the rest of elements and teaching subjects [...]" (Janowski, 2015, p. 110). 
The first phase of training, called selective training, is intended to determine each candidate's predisposition to the pilot profession. Regarding the latter, there can be mentioned features such as: divisibility of attention, psychophysical and manual skills and ability to proper exploitation of the aircraft. This phase is also meant to present the flying possibilities of the machines as well (Bogusz, Kulik, 2014).

After the first stage the cadets take basic training in the Academic Centre of Aviation Training. This allows them to gain a private pilot license (PPL) which is necessary for further education. During this time students are assigned to one specialization (Bogusz, Kulik, 2014):

- jet aircraft,

- transport aircraft,

- helicopters.

The third phase of training, which is realized on military aircraft, take place in the $4^{\text {th }}$ Training Aviation Wing and is divided into two stages: basic and advanced training. The first part's purpose is to check the mastery of basic pilotage elements. The advanced training is to prepare candidates for the next stage of training by realizing following tasks on military aircraft (Bogusz, Kulik, 2014):

- combat airborne targets,

- combat ground targets,

- visual - photographic reconnaissance,

- exercise group flights,

- exercise navigational skills during en-route flights.

The tactical training is the last stage of the training process which is realized according to the type of aircraft and the nature of combat units.

The training program plays an important role in the pilot's education process. It is very important to construct it very carefully. We should understand it as follows: it allows to gain appropriate theoretical knowledge and practical skills. This is interpreted as equivalent to achieving a proper level of aviation safety. It would not be possible without a risk management process which is consisted of six phases showed on figure 2 .

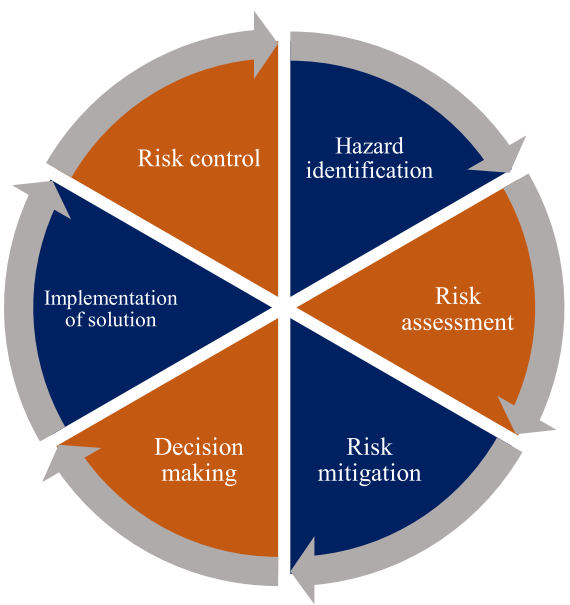

Figure 2. Risk management

Source: own material based on: Klich, 2011, p. 189-219. 
The main aim of the risk management process is to assess the probability of the occurrence of threats and minimalizing risk level to acceptable. Below there are shortly described phases of this process.

1. The first phase (hazard identification) is to define (as many as possible) threats for performed tasks. Every employee in organizations, institutions, etc. should be prepared and able to identify the threats and inform other people, especially the superiors, about the hazards. During this part, there should be done a precise task analysis, specified list of threats and list of probable causes of threats.

2. The second phase of the risk management, generally called risk assessment, is nothing more than estimation of the probability of risk occurrence and determination of the severity of risk adverse effects. It consists of four steps: risk assessment in terms of exposure, assessment of the likelihood of each threat, assessment of the severity of each threat and then there should be done a complete risk assessment. We have to remember that if the level of risk is unacceptable (too high) it is necessary to continue the risk management process but if the level of risk is on acceptable or lower level it is required to monitor the possible risk.

3. The third phase of risk management (understood as risk mitigation) is identification of possible solutions to minimize risk, their potential impacts on task and indication of the most effective measures designed to reduce the risk.

4. The fourth stage (decision making) consists of two steps. The first relies on the chosen method of risk control, the next one is making a decision. During this phase it is important to select the most effective solution for the task's safety.

5. The fifth phase (implementation of the solution) is determination of the right entity or person responsible for the decision-making and implementation of the accepted variant.

6. The sixth phase (risk control) is verification of the efficacy of the adopted solutions. It is done by analysis, evaluation of the effectiveness of the implemented procedure and appropriate reaction adapted to the situation.

We have to remember that none of the risk management process phases should be ignored. What is important is that every previous stage ought to be the basis for the next phases in this process. It is essential to know that the risk management is a cyclical process. It means nothing more than that after completion of every phase there should be a redefinition of the possible threats. In case of their occurrence it is essential to implement the process again.

The above mentioned military pilots training system was introduced at the beginning of the twenty-first century to improve the level of aviation safety in military aviation training units. To demonstrate the necessity of applied changes, there is prepared an analysis of aircraft accidents occurred in military aviation training units in the years 1970-1994 (the old training system was used at that time).

\section{CAUSES OF THE AIRCRAFT ACCIDENTS OCCURRED IN UNITS OF THE POLISH AIR FORCE ACADEMY IN THE YEARS 1970-1994}

Aviation safety is dependent on interactions between factors related to aviation safety model. These are:

- the human factor generally understood as the aircraft operator,

- the aircraft, it means its technical condition, performance, also operational restrictions, 
- environment, that is the air space with all the physical characteristics, infrastructure and every technical device connected with performing an operation,

- organization, that is regulations, procedures and management of the aviation institution.

Aviation accidents, regardless of the type of aviation, are invariably caused by the same factors. According to considered topic it is possible to divide the aviation accidents into two groups: dependent and independent on aviation personnel. The first ones result from:

- errors during pilotage,

- indiscipline of the flight crew,

- incorrect aircraft's exploitation by the technical personnel,

- inadequate aircraft's servicing by technical personnel.

Independent reasons consist of:

- manufacturing defects,

- other causes not related to human activities, for example meteorological conditions.

Errors in pilotage are often a result of the need to focus on many devices in the cockpit and to perform a large number of activities in a short period of time. These factors have a negative impact on a pilot's work. What is more, these could be the cause of wrong data reading or missing important information for a task.

Indiscipline of the flight crew can be the cause of violations. "[...] perpetrators of violations know that their behavior departs from established procedures, schemes of proceeding, standards and practices but they do it intentionally" (Urząd Lotnictwa Cywilnego [ULC], 2009b). This is nothing more than a deliberate action. These proceedings will result in reduction of security level, which may manifest with loss of spatial orientation or reduction of the required separation minimum.

Other factors which generate threats for aviation are incorrect aircraft's exploitation and servicing. These may result from routine, neglect and desire to obtain economic benefits. People who use and prepare machines for flights are responsible for safety of the passengers, crews and aircraft's technical condition.

It is required from pilots to know a large number of procedures, augmentation and navigation systems. This will not be possible without the appropriate training process. It is very important because theoretical knowledge, practical skills and other acquired habits will be used in the workplace.

Aviation accidents occurred because of, for example, manufacture defects or exploited components, are impossible to avoid. This is due to construction of aircraft that are built of many cooperating mechanisms and devices. The above mentioned components work together so this may cause the parts' damage. It is also impossible to avoid aviation accidents occurred due to rapid change of meteorological conditions. These include storms with lightning, fogs, heavy rains, wind shares during landing and strong wind.

\section{ANALYSIS OF THE AIRCRAFT ACCIDENTS OCCURRED IN UNITS OF THE POLISH AIR FORCE ACADEMY IN THE YEARS 1970-1994}

The following analysis was carried out on the basis of data collected from flight safety information brochures which were publicized in the Polish Air Force Academy from 1975 to 1998 (Gilos, Krasoń, 1979; Klich, 1983, 1985, 1986, 1988; Klich, Krupka, 1998; Krasoń, 1980, 1981; Krupka, 1994; Majewski, 1984a, 1984b; Nowak, 1975, 1976, 1977). The aim of this analysis was to obtain 
and present information about the whole number of aviation accidents occurred in the years 1970-1994. What is more important, it was done to identify the percentage ratio of accidents caused by the human factor.

As it is shown in table 1, the percentage of accidents dependent on human did not stay at the same level each year. The majority of them oscillated between 40 and 70\%. It was impacted by:

- flying hours on each aircraft type,

- experience, discipline and conscientiousness of people involved in the tasks implementation,

- the way of aircraft exploitation,

- correctness of technical servicing of aircraft,

- weather conditions and many other factors.

Table 1. List of aviation accidents occurred in units of the Polish Air Force Academy from 1970 to 1994 and percentage ratio of accidents caused by human

\begin{tabular}{|c|c|c|c|c|}
\hline & $\begin{array}{l}\text { Accidents } \\
\text { dependent } \\
\text { on human }\end{array}$ & $\begin{array}{c}\text { Accidents } \\
\text { independent } \\
\text { on human }\end{array}$ & $\begin{array}{l}\text { Total number } \\
\text { of accidents }\end{array}$ & $\begin{array}{c}\text { Percentage } \\
\text { ratio } \\
\text { of accidents } \\
\text { caused } \\
\text { by human }\end{array}$ \\
\hline 1970 & 0 & 2 & 2 & 0.00 \\
\hline 1971 & 5 & 6 & 11 & 45.45 \\
\hline 1972 & 10 & 9 & 19 & 52.63 \\
\hline 1973 & 4 & 4 & 8 & 50.00 \\
\hline 1974 & 10 & 4 & 14 & 71.43 \\
\hline 1975 & 5 & 9 & 14 & 35.71 \\
\hline 1976 & 11 & 4 & 15 & 73.33 \\
\hline 1977 & 11 & 6 & 17 & 64.71 \\
\hline 1978 & 8 & 6 & 14 & 57.14 \\
\hline 1979 & 10 & 3 & 13 & 76.92 \\
\hline 1980 & 11 & 8 & 19 & 57.89 \\
\hline 1981 & 10 & 9 & 19 & 52.63 \\
\hline 1982 & 12 & 2 & 14 & 85.71 \\
\hline 1983 & 4 & 8 & 12 & 33.33 \\
\hline 1984 & 3 & 3 & 6 & 50.00 \\
\hline 1985 & 3 & 4 & 7 & 42.86 \\
\hline 1986 & 7 & 5 & 12 & 58.33 \\
\hline 1987 & 3 & 6 & 9 & 33.33 \\
\hline 1988 & 2 & 10 & 12 & 16.67 \\
\hline 1989 & 6 & 6 & 12 & 50.00 \\
\hline 1990 & 8 & 11 & 19 & 42.11 \\
\hline 1991 & 5 & 5 & 10 & 50.00 \\
\hline 1992 & 1 & 9 & 10 & 10.00 \\
\hline 1993 & 0 & 5 & 5 & 0.00 \\
\hline 1994 & 5 & 8 & 13 & 38.46 \\
\hline $\begin{array}{l}\text { Total } \\
\text { number }\end{array}$ & 154 & 152 & 306 & 50.33 \\
\hline
\end{tabular}

Source: own material based on: Flight safety brochures published by the Polish Air Force Academy from 1975 to 1998 (Gilos, Krasoń, 1979; Klich , 1983, 1985, 1986, 1988; Klich, Krupka, 1998; Krasoń, 1980, 1981; Krupka, 1994; Majewski, 1984a, 1984b; Nowak, 1975, 1976, 1977). 
On the basis of data contained in table 1, the conclusion is as follows: there were 306 aviation accidents in concerned period of time. Most of them, which is 154 (50.33\%), were caused by the human factor (pilots, air traffic controllers, technical personnel and other). A result at this level is not satisfactory because it shows a man to be the weakest element of aviation safety system.

The largest participation of the human factor in concerned aviation accidents (over 70\%) took place in years: 1974, 1976, 1979, 1982 (fig. 3) and the lowest (below 40\%) in: 1970, 1975, 1983, 1987, 1988, 1992, 1993, 1994 (fig. 4). The rest of the time, these accidents classify between $40-70 \%$ but vast majority of them falls into $50-60 \%$ category.

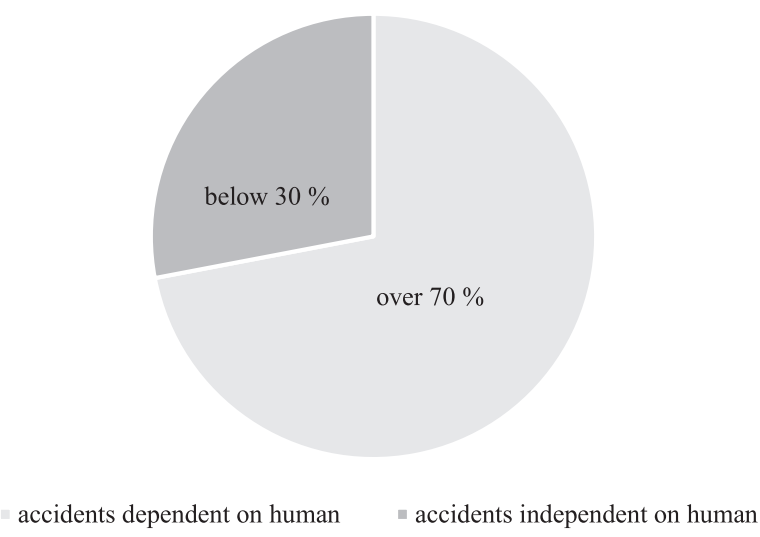

Figure 3. Accidents dependent and independent on human - classification of aviation accidents occurred in units of the Polish Air Force Academy in years: 1974, 1976, 1979, 1982

Source: own material based on Flight safety brochures published by the Polish Air Force Academy from 1975 to 1998 (Gilos, Krasoń, 1979; Klich, 1983, 1985, 1986, 1988; Klich, Krupka, 1998; Krasoń, 1980, 1981; Krupka, 1994; Majewski, 1984a, 1984b; Nowak, 1975, 1976, 1977).

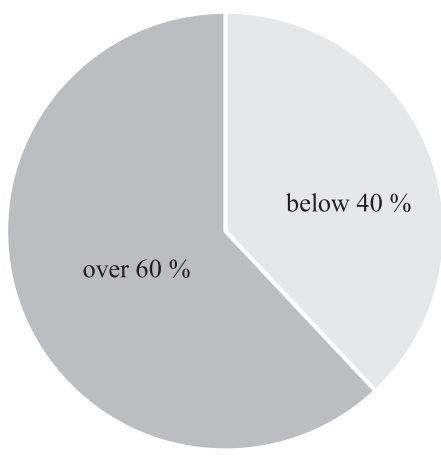

accidents dependent on human accidents independent on human

Figure 4. Accidents dependent and independent on human - classification of aviation accidents occurred in units of the Polish Air Force Academy in years: 1970, 1975, 1983, 1987, 1988, 1992, 1993, 1994

Source: own material based on Flight safety brochures published by the Polish Air Force Academy from 1975 to 1998 (Gilos, Krasoń, 1979; Klich, 1983, 1985, 1986, 1988; Klich, Krupka, 1998; Krasoń, 1980, 1981; Krupka, 1994; Majewski, 1984a, 1984b; Nowak, 1975, 1976, 1977). 
A detailed analysis should be done with the years 1974 and 1975. As we can see, there was the same number of accidents in both years but in 1975 there were about 35.72\% less accidents caused by human activity than the year before. This may be due to enormous aviation personnel's commitment in training process in units of the Polish Air Force Academy and implementation of various prevention activities which were taken after consideration of previous aviation accidents (Nowak, 1976).

There was a similar situation in 1992. The number of aviation accidents which resulted because of human failure was about $40 \%$ less than in 1991. This was also thanks to the Polish Air Force Academy personnel's commitment in improving safety level by implementation of prevention activities (Krupka, 1994).

\section{CONCLUSION}

The presented considerations show that the level of flight safety depends on many factors. The main one is the human factor. It is the cause of majority of aviation accidents in units of the Polish Air Force Academy in considered period of time.

People elaborate on aviation regulations, procedures, aircraft constructions and of course they are responsible for technical condition of the aviation ground infrastructure as well. Therefore, it is necessary to regularly improve the theoretical knowledge and practical skills of aviation personnel. It has to decrease the number of aviation accidents manifested by mistakes, violations and other undesirable behavior. But this is not enough. It is very important to adjust technical and tactical parameters of aircraft to human possibilities. Statistics show that in the US Air Forces there were nine crashes caused by the pilot's unconsciousness from 1983 to 1984 (Klich, 2011). As we can see, it is necessary to obey the mentioned principles because aviation safety depends on interactions between human, aircraft, organisation and environment.

The above prepared analysis clearly demonstrates that updating training programs is essential. This is due to the necessity to improve the level of safety during tasks performance in military aviation training units.

Despite of discussed period of time (colloquially it can be said, it is historical topic) we have to know that above considerations are still current. The main causes of aviation accidents, as it was presented in previous parts of article, are divided into two main groups: dependent and independent on human. What is more, there are more accidents occurred because of wrong activity of the human factor. According to statistical data referring to these kinds of accidents in Polish Air Force from 1986 to 1995, 56\% of accidents were caused by human (Karpowicz, Klich, 2011). In case of civil aviation there is a similar situation: $73 \%$ of accidents were caused by the human factor from 2003 to 2008 (Urząd Lotnictwa Cywilnego [ULC], 2009a). It should be added that contemporary aircraft and other technical devices are better constructed due to technological progress. Because of that, nowadays the human factor is the most dangerous for aviation safety and for this reason it is extremely important to pay attention to the selection of candidates and the training process.

\section{REFERENCES}

Bogusz, D., Kulik, T. (2014). Szkolenie lotnicze kandydatów na pilotów wojskowych w Akademickim Ośrodku Szkolenia Lotniczego WSOSP. Zeszyty Naukowe AON, 3 (96), p. 138-139.

Gilos, J., Krasoń, A. (1979). Informator bezpieczeństwa lotów za lata 1977-1978. Dęblin: WOSL. 
Janowski, C. (2015). Zdolności a system szkolenia. Przegląd Sił Zbrojnych, 3, 110.

Karpowicz, J., Kich E. (2011). Zarządzanie bezpieczeństwem w lotnictwie. Dęblin: WSOSP.

Klich, E. (1983). Informator bezpieczeństwa lotów za rok 1981. Dęblin: WOSL.

Klich, E. (1985). Informator bezpieczeństwa lotów za rok 1983. Dęblin: WOSL.

Klich, E. (1986). Informator bezpieczeństwa lotów za rok 1984. Dęblin: WOSL.

Klich, E. (1988). Informator bezpieczeństwa lotów za rok 1986. Dęblin: WOSL.

Klich, E. (2011). Bezpieczeństwo lotów. Radom: Wydawnictwo Biblioteki Problemów Eksploatacji.

Klich, E., Krupka, J. (1998). Informator bezpieczeństwa lotów za lata 1993-1994. Dęblin: WSOSP.

Krasoń, A. (1980). Informator bezpieczeństwa lotów za rok 1979. Dęblin: WOSL.

Krasoń, A. (1981). Informator bezpieczeństwa lotów za rok 1980. Dęblin: WOSL.

Krupka, J. (1994). Informator bezpieczeństwa lotów za lata 1988-1992. Dęblin: WSOSP.

Majewski, A. (1984a). Informator bezpieczeństwa lotów za rok 1982.Dęblin: WOSL.

Majewski, A. (1984b). Nadzwyczajny informator bezpieczeństwa lotów. Wypadki lotnicze zaistniałe w Wyższej Oficerskiej Szkole Lotniczej w latach 1947-1983 spowodowane niezdyscyplinowaniem personelu latającego. Dęblin: WOSL.

Makarowski, R., Smolicz, T. (2012). Czynnik ludzki w operacjach lotniczych. Człowiek, możliwości i ograniczenia - uwarunkowania psychofizjologiczne. Kosowizna: Wydawnictwo ADRIANA AVIATION spółka z o.o.

Nowak, H. (1975). Informator bezpieczeństwa lotów. Wypadki lotnicze i ważniejsze przesłanki do wypadków lotniczych zaistniałe w jednostkach WOSL w 1974 roku. Dęblin: WOSL.

Nowak, H. (1976). Informator bezpieczeństwa lotów. Wypadki lotnicze i ważniejsze przesłanki do wypadków lotniczych zaistniałe w jednostkach WOSL w 1975 roku. Dęblin: WOSL.

Nowak, H. (1977). Informator bezpieczeństwa lotów. Wypadki lotnicze i ważniejsze przesłanki do wypadków lotniczych zaistniałe w jednostkach WOSL w 1976 roku. Dęblin: WOSL.

Polish Aviation Law of 3 July 2002.

ULC. (2009a). Biuletyn informacyjny BL, 2009 (02/2009), Warszawa.

ULC. (2009b). Podręcznik zarządzania bezpieczeństwem, Warszawa.

Analiza wypadków lotniczych zaistniałych w jednostkach Wyższej Oficerskiej Szkoły Lotniczej w latach 1970-1994

STRESZCZENIE Poniższy artykuł został napisany w oparciu o Informatory bezpieczeństwa lotów, wydane w Wyższej Szkole Oficerskiej Sił Powietrznych w latach 1975-1998. W części pierwszej opisano aktualny proces szkolenia pilotów wojskowych w Polsce. Następnie scharakteryzowano główne przyczyny wypadków lotniczych w jednostkach Wyższej Szkoły Oficerskiej Sił Powietrznych w rozpatrywanym okresie. W ostatniej części artykułu poddano analizie wypadki zaistniałe w jednostkach szkolnych w latach 19701994.

SŁOWA KLUCZOWE bezpieczeństwo lotów, czynnik ludzki, szkolenie, wypadek lotniczy

Translated by Marek Kustra 